\title{
DETERMINANTS OF DAY CARE TEACHERS' JOB SATISFACTION
}

\author{
Bianca Kusma ${ }^{1,2}$, David A. Groneberg ${ }^{1}$, Albert Nienhaus ${ }^{3}$, Stefanie Mache ${ }^{1,4}$ \\ ${ }^{1}$ Institute of Occupational Medicine, Social Medicine and Environmental Medicine, Goethe-University, Frankfurt, Germany \\ ${ }^{2}$ Department of Respiratory Medicine, Hannover Medical School, Hannover, Germany \\ ${ }^{3}$ Institution for Statutory Accident Insurance in the Health and Welfare Services, Hamburg, Germany \\ ${ }^{4}$ Department of Medicine/Psychosomatics, Charité-Universitätsmedizin Berlin, Free University and Humboldt University, Berlin, Germany
}

\section{SUMMARY}

Background: Although job satisfaction is among the most widely researched topics, relatively little research has been done on this issue as it relates to early childhood educators. This study was designed to contribute significantly to the deficient body of knowledge about working conditions and job satisfaction of day care teachers, in particular with regard to differences in job satisfaction depending on day care centres' ownership.

Methods: Analyses were based on cross-sectional comparison of 469 questionnaires ( $42.55 \%$ response rate) from day care teachers working at public day care centres with those working at day care centres run by churches or parents' initiatives.

Results: A significant difference in job satisfaction was found between these three types. The important interaction between socio-demographic characteristics, psychosocial working conditions, and job satisfaction could be demonstrated.

Conclusion: The present study is one of the few that examines the impacts of day care centres ownership on pedagogical staffs' job satisfaction and indicates that the type of the centre is a potential factor explaining variations. Results provide a valuable basis for the development of solution-focused approaches to improve pedagogical staff working conditions.

Key words: day care teacher, job satisfaction, job demands-resources model, ownership

Address for correspondence: Bianca Kusma, Institute of Occupational Medicine, Social Medicine and Environmental Medicine, Goethe-University, Theodor-Stern-Kai 7, 60590 Frankfurt, Germany. E-mail: Kusma@em.uni-frankfurt.de

\section{INTRODUCTION}

Job satisfaction is among the most widely researched topics. Reasons therefore are evident: this issue has strong appeal because it is immediately relevant to one's own life. People spent much of their time at work, so understanding the factors involved in achieving fulfilment can have an impact on personal well-being of employees (1). Nevertheless, relatively little research has been done on this topic as it relates to early childhood educators.

Although job satisfaction has first and foremost personal relevance, one can assume a direct causal link between educators' feelings of satisfaction and their productivity at work. This assumption is confirmed by the fact that low job satisfaction is one of the factors that affect the intention to leave and early retirement $(2,3)$. Rates show that turnover is more frequent in child care centres than in any other teaching setting $(4,5)$. This is difficult to tolerate as it has been associated with compromised development of children and lower-quality service (5-8). Furthermore this high rate puts an enormous strain on programmes that must search out and retrain new staff (1).

This study was designed to provide a more detailed knowledge of different aspects on nursery school teachers' job satisfaction, in particular with regard to differences in job satisfaction depending on day care centres' ownership. Day care teachers working at public day care centres were compared with those working at day care centres run by churches or parents' initiatives (9).
Additional research is needed to examine how child care teachers respond to structural components or conditions of their work helping policymakers and managers of day care centres to support caregivers. This may result in increased job satisfaction, contributing to an overall improvement of child care.

\section{Theoretical Background}

Multiple factors have an impact on job satisfaction. The Job Demands-Resources Model (JD-R model) (10) is a theoretical approach that tries to explain the relationship between psychosocial working conditions and well-being. The JD-R model was primarily developed to explain burnout. Depending on the context under study, it is possible to comprise various demands and resources. Therefore the JD-R model is also appropriate to explain well-being at work and job satisfaction (11-13). Robustness of the model was confirmed by Llorens et al. (14). According to the JD-R model the work environment is characterized by two general categories: job demands and job resources (10).

Job demands include those physical, social, or organizational aspects of work that require continuing physical and/or psychological effort (i.e. cognitive or emotional). For that reason job demands are associated with physiological and/or psychological costs (e.g. exhaustion) $(15,16)$. Job demands are not inevitably negative. Nevertheless, they may turn into job stressors when facing those demands requires high effort from which the employee 
does not appropriately recover (17). Job demands of pedagogical staff include quantitative demands like multitude of job tasks (18) and also time pressure $(19,20)$, physical demands (21-23), emotional demands (21) and demands for hiding emotions (22). These job demands may differ depending on day care centres' ownership.

Job resources refer to physical, social, or organizational aspects of the job that (1) are functional in achieving work-related goals, (2) reduce job demands and the associated physiological and psychological costs, and (3) stimulate personal growth and development (10). According to Bakker and Demerouti (2007), job resources can be located at the level of the organization at large (e.g. pay, career opportunities, job security), the interpersonal and social relations (e.g. support of supervisor and co-workers, team climate), the organization of work (e.g. role clarity, participation in decision making), and at the level of tasks (e.g. skill variety, task identity, task significance, autonomy, performance feedback) (24). The availability of job resources plays a motivational role because they foster employees' growth, learning and development (25).

\section{Job Satisfaction}

Job satisfaction is an affective reaction to an individual's work situation. In accordance with Rice et al. (1991), it can be defined as an overall feeling about one's job or career or in terms of specific facets of the job or career (e.g. compensation, autonomy, co-workers) and it can be associated with specific outcomes, for example productivity (26). Despite the fact that a considerable amount of research has been done into the determinants of job satisfaction (27-29), less attention has been paid so far to dissimilarities between different types of ownerships (12). Only a few studies revealed mixed results in employees' job satisfaction across different types of ownership.

Wong (2010) showed that teachers in non-profit-making (NPM) kindergartens had higher job satisfaction and lesser mental health complaints than employees of profit-making (PM) kindergartens (30). Conversely, Mullis et al. (2003) found no significant differences in job satisfaction between directors in NPM and PM childcare centres (31). As findings are inconsistent, the following hypotheses need to be tested:

Hypothesis 1: Job satisfaction of day care teachers differs significantly depending on day care centres' ownership.

Previous research has shown that job characteristics can have a profound impact on employee job satisfaction $(32,33)$. The JD-R model prognosticates an increase of emotional exhaustion and a decrease of job satisfaction when high job demands are experienced. Job resources, however, can reduce emotional exhaustion and increase job satisfaction $(10,13)$.

Hypothesis 2a: High levels of perceived job demands are negatively related to job satisfaction.

Hypothesis 2b: High levels of perceived job resources are positively related to job satisfaction.

Personality characteristics can also have an influence on how individuals handle different demands related to work and wellbeing. Previous research on the Job Demand-Resources Model has been restricted to work related factors of job satisfaction (15). Thus, the role of employees' personal resources has been neglected (e.g. coping and adaptation skills to manage job demands). According to Hobfoll and colleagues (2003), personal resources are features of the self that are generally linked to resiliency and refer to persons' sense of ability to control and impact the environment successfully $(15,34)$.

Findings from studies corroborated the importance of taking personality variables into consideration during the process of evaluating job satisfaction $(35,36)$. In a recent investigation Mache et al. (2009) demonstrated that job demands and resources as well as personal resources are almost equally important aspects of physicians' job satisfaction (12). One can assume that there are similar associations for day care teachers.

Hypothesis 2c: Job demands, job resources, and personal resources each contribute additional unique variance in relation to the work-related outcomes of job satisfaction.

\section{MATERIALS AND METHODS}

\section{Research Design and Participants}

A cross-sectional survey employing a standardized questionnaire to assess child care teachers' socio-demographic data, psychosocial working conditions and job satisfaction was conducted.

Invitations to take part in the study were made to $\mathrm{n}=165$ day care centres. These facilities, all located in a large German city, were randomly selected with regard to their type of ownership (public, confessional, parents' initiative). Participating day care centres varied greatly in size: the smallest had two employees, the largest 40. Data collection process took place between March and December 2010. The questionnaire was distributed together with a letter of invitation, the purpose of the study and a reply envelope. Child care teachers were informed that participation in the study was completely voluntary and anonymous. Therefore, informed consent was implied if educators completed and returned their questionnaire. In total, 500 of the 1,100 nursery school teachers who received questionnaires returned them (response rate $45 \%$ ). Four hundred sixty-nine usable questionnaires were sent back.

\section{Ethics}

The ethical aspects were in full agreement with the Helsinki Declaration. Due to the fact that the study was carried out as an anonymous survey and participation was voluntary, an approval by an ethics committee was not required.

\section{Instrument}

\section{Socio-demographic Data of Respondents}

Items on the questionnaire pertained to pedagogical staffs socio-demographic characteristics, such as gender, year of birth, family status and children. Details on nursery school teachers' professional background were also collected (i.e. education specialty, years of experience). In addition, the type of day care centre ownership (public, church or parents' initiatives) at the educators' institution was also assessed.

\section{Psychosocial Work Factors}

Job-related and psychosocial factors at work were measured with the German version of the Copenhagen Psychosocial Questionnaire (COPSOQ) (37) - with the exception of "physical demands" (22). The instrument applied in this survey consists of 12 scales concerning job demands (i.e. emotional demands), job 
resources (i.e. social support, possibilities for development) and job outcome (i.e. job satisfaction). Previous research corroborate reliability, validity and applicability of the COPSOQ (37).

\section{Demands at Work}

Quantitative demands were assessed with four items $(\alpha=0.75)$, e.g. "How often do you not have time to complete all your work tasks". Emotional demands were measured with three items $(\alpha=0.76)$, e.g. "Is your work emotionally demanding". Demands for hiding emotions were obtained with two items $(\alpha=0.71)$ "Does your work require that you hide your feelings". Physical demands (22) were analysed with three items $(\alpha=0.63)$, for example "Is your work physically hard".

\section{Job Resources}

Possibilities for development were obtained with four items ( $\alpha=0.72$ ), with questions such as "Do you have the possibility of learning new things through your work". The influence at work scale contained four items $(\alpha=0.72)$, e.g. "Do you have a large degree of influence concerning your work". Quality of leadership was measured with four items $(\alpha=0.88)$, e.g. "To what extent would you say that your immediate superior gives high priority to job satisfaction". Sense of community was assessed with three items $(\alpha=0.83)$, with questions such as "Is there a good atmosphere between you and your colleagues". Social support was analysed with four items $(\alpha=0.66)$, e.g. "How often do you get help and support from your colleagues". Degree of freedom at work were obtained with four items $(\alpha=0.63)$, e.g. "Can you decide when to take a break". Meaning of work was assessed with three items $(\alpha=0.77)$, for example "Is your work meaningful".

All items were scored on a five-point Likert scale either to assess the extent to which a statement applied to the participant (from "to a very large extent" to "to a very small extent") or to indicate the frequency of an occurrence (from "always" to "never/hardly ever") (38). One exception was "physical demands", which were assessed with a 4-point answering scale (from "never" to "to a very large extent").

\section{Job Satisfaction}

The outcome measure job satisfaction was assessed using a 7-item scale $(\alpha=0.78)$ asking participants to rate their work in general with questions such as "How pleased are you with the way your abilities are used?" Items were scored on a 4-point Likert scale (from "very satisfied" to "highly unsatisfied").

\section{Personal Resources}

In order to examine the role of personal resources in the process of evaluating job satisfaction, three typical resources were assessed, namely resilience, self-efficacy and optimism. Resilience, defined as the ability to successfully cope with change or misfortune (39), was obtained with the German version of the Brief Resilient Coping Scale (BRCS; $\alpha=0.72$ ). The instrument consists of four items, e.g. "Regardless of what happens to me, I believe I can control my reaction to it." Each item was rated on a 5-point scale ("strongly agree" to "strongly disagree") (40). In addition the questionnaire Self-Efficacy, Optimism and Pessimism (SWOP-K9) (41) was included too. This instrument is composed of the questionnaire on general expectation of self-efficacy (42) and the Life Orientation Test (LOT) (43), which captures the outcome expectation. Optimism is measured with two items $(\alpha=$
$0.81)$, e.g. "I'm always optimistic about my future". Self-Efficacy was assessed with five items $(\alpha=0.73)$, for example "I face difficulties with relative ease because I can count on my abilities". Items were scored on a 5-point Likert scale (from "always" to "never/hardly ever").

\section{Analysis}

In accordance with Nübling and colleagues (37), the categorical items pertaining to demands at work, job resources and job satisfaction were transformed on a value range from 0 (minimum, for instance "do not agree at all") to 100 points (maximum value, for instance: "fully agree"). Non-response behaviour to items and the category "does not apply" was processed as missing data. Calculation of scale values was carried out as mean of values of the single aspects (37). All scores followed a normal distribution.

Frequency distributions were used to describe respondents' demographic characteristics. Statistically significant differences in job satisfaction with respect to the three ownership types were evaluated by one-way analysis of variance (ANOVA). Person correlations were performed to capture relationships between variables.

In order to answer the question to which degree job satisfaction was dependent on day care teachers' demands and resources, a hierarchical regression analysis was carried out. The regression model with the dependent variable 'job satisfaction' comprised four blocks. First, the socio-demographic variables (age, years of experience) were entered. Next, with the second block, the personal resources (i.e. self-efficacy) were assessed. Third, the job demands (i.e. demands for hiding emotions) were entered. Finally, the fourth block contained the job resources (i.e. social support, possibilities for development).

All p-values given were two-tailed. Statistical significance was set at $\mathrm{p}<0.05$. Values are given as mean and standard deviation (SD). Data were analysed using PASW statistics version 18.

\section{RESULTS}

\section{Descriptive Statistics}

In the total sample almost all subjects were females (95.2\%) with an average age of 44.8 years $(\mathrm{SD}=9.8$ years, range $21-63)$. The overwhelming majority of participants hold a degree as an early childhood educator (93.6\%); only 17 hold an university degree in education (3.6\%). On average, the pedagogical staff had 20.6 years of work experience $(\mathrm{SD}=11.1$ years). Table 1 summarizes the socio-demographic data of the participating child care teachers depending on the three different ownership types.

\section{Job Satisfaction and Type of Centre}

Hypothesis 1 predicted a significant difference in nursery school teachers' job satisfaction depending on day care centres' ownership. Employees working at public day care centres $(\mathrm{M}=58.49 ; \mathrm{SD}=12.17)$ rated their job satisfaction lower than those working at day care centres run by churches $(M=64.45$; $\mathrm{SD}=14.17)$ or parents' initiatives $(\mathrm{M}=66.86 ; \mathrm{SD}=13.23)$. This statistically significant difference $\left(\mathrm{F}_{2,466}=19.63, \mathrm{p}<0.001\right)$ support hypothesis 1 (Table 2). 
Table 1. Personal characteristics of the participants with regard to day care centres' ownership

\begin{tabular}{|l|c|c|c|}
\hline \multirow{2}{*}{} & Public & Confessional & Parents' initiatives \\
\cline { 2 - 4 } & $(\mathrm{N}=226)$ & $(\mathrm{N}=136)$ \\
\hline Age & $18(8.1 \%)$ & $14(13.1 \%)$ & $43(31.9 \%)$ \\
\hline $35-44$ years & $49(22.2 \%)$ & $32(29.9 \%)$ & $50(37 \%)$ \\
\hline $45-54$ years & $110(49.8 \%)$ & $35(32.7 \%)$ & $31(23 \%)$ \\
\hline$\geq 55$ years & $44(19.9 \%)$ & $26(24.3 \%)$ & $11(8.1 \%)$ \\
\hline Mean (SD) & $47.2(8.3)$ & $46.6(10.1)$ & $39.6(9.8)$ \\
\hline Gender (female) & $221(97.8 \%)$ & $100(93.5 \%)$ & $125(91.9 \%)$ \\
\hline Specialty in education & & & \\
\hline Early childhood educator & $218(96.4 \%)$ & $95(88.8 \%)$ & $126(92.7 \%)$ \\
\hline University degree in education & $4(1.8 \%)$ & $6(5.6 \%)$ & $7(5.1 \%)$ \\
\hline Other & $4(1.8 \%)$ & $6(5.6 \%)$ & $3(2.2 \%)$ \\
\hline Years of experience & & & \multicolumn{2}{|c|}{} \\
\hline$<10$ years & $17(7.6 \%)$ & $27(25.2 \%)$ & $49(37.7 \%)$ \\
\hline $10-19$ years & $13(5.8 \%)$ & $25(23.4 \%)$ & $48(36.9 \%)$ \\
\hline $20-29$ years & $122(54.7 \%)$ & $30(28 \%)$ & $23(17.7 \%)$ \\
\hline $30-39$ years & $65(29.1 \%)$ & $20(18.7 \%)$ & $9(6.9 \%)$ \\
\hline$\geq 40$ years & $6(2.7 \%)$ & $5(4.7 \%)$ & $1(0.8 \%)$ \\
\hline Mean (SD) & $25.6(9.1)$ & $19(11.5)$ & $13.2(9.3)$ \\
\hline
\end{tabular}

Determinants of Day Care Teachers' Job Satisfaction

For Hypothesis $2 \mathrm{a}$ and $2 \mathrm{~b}$, which stated that high levels of perceived job demands are associated with low levels of job satisfaction whereas high levels of perceived job resources are associated with high levels of job satisfaction, correlations were performed. The results of the analysis are displayed in Table 3. Work demands correlated significantly negative with job satisfaction in all cases, although the magnitude of correlation was quite variable, ranging from -0.17 to $-0.39(\mathrm{p}<0.01)$. Likewise job resources correlated significantly positive with job satisfaction $(r=0.23$ to $r=0.57, p<0.01)$. Positive correlations were also found between job satisfaction and all personal resources $(\mathrm{r}=0.15$ to $\mathrm{r}=0.32, \mathrm{p}<0.01)$.

Taken together, these results confirm the assumptions of the corresponding hypotheses.

In order to identify determinants of day care teachers' job satisfaction block-wise multiple regression analyses were performed. F-ratios of all four models were highly significant. Table 4 illustrates standardized coefficients (Beta) and percentages of explained variance of each model.

The socio-demographic variables explained solely a marginal portion of the variance $(2 \%)$. A significantly negative beta weight for years of experience $(\beta=-0.24, p<0.01)$ was observed. With inclusion of personal resources in the second step additionally $12 \%$ of the variance could be explained.

In the third step, the job demands explained an additional 15\% of the variance in job satisfaction. Except for emotional demands all other job demands represented a significantly negative beta weight.

Finally, addition of the job resources in the fourth step yielded an increase of $28 \%$ of the variance explained. Of the seven job resources, four (influence at work, meaning of work, quality of leadership, and sense of community) had significantly positive beta weights.

The model showed a rather good fit: $57 \%$ of the observed variance in job satisfaction was explained. These results support Hypothesis 2c.

\section{DISCUSSION}

The purpose of the present study was to investigate differences in job satisfaction between employees of day care centres with different ownership types (public, confessional, and parents' initiatives). Due to the fact that job satisfaction is one of the factors that is associated with early retirement $(2,3)$ and intention to

Table 2. Differences in job satisfaction with regard to day care centres' ownership

\begin{tabular}{|c|c|c|c|c|c|c|c|c|c|}
\hline & \multicolumn{2}{|c|}{ Public } & \multicolumn{2}{|c|}{ Confessional } & \multicolumn{2}{|c|}{ Parents' initiatives } & \multirow{2}{*}{ F-value } & \multicolumn{2}{|c|}{ Covariates F-tests } \\
\hline & M & SD & M & SD & M & SD & & Age & Experience \\
\hline Job satisfaction & 58.49 & 12.17 & 64.45 & 14.17 & 66.86 & 13.23 & $19.63^{* * *}$ & 0.72 & 1.09 \\
\hline
\end{tabular}




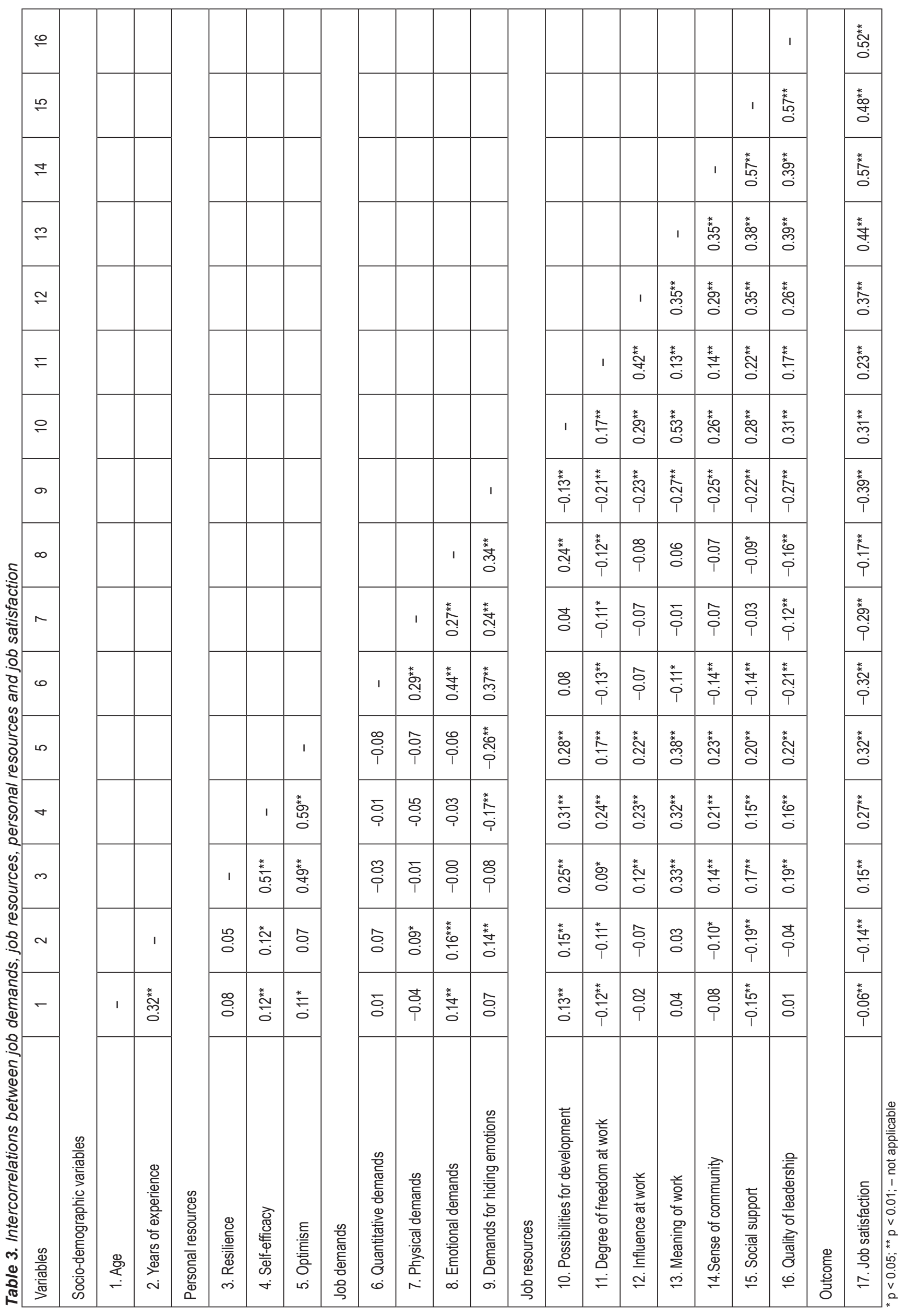


Table 4. Summary of linear regression analyses on variables to explain variance in educators' job satisfaction

\begin{tabular}{|c|c|c|c|c|}
\hline \multirow{2}{*}{$\begin{array}{l}\text { Independent variables } \\
\text { Model }\end{array}$} & \multicolumn{4}{|c|}{$\begin{array}{c}\text { Job satisfaction } \\
\beta \\
\end{array}$} \\
\hline & 1 & 2 & 3 & 4 \\
\hline \multicolumn{5}{|l|}{ Socio-demographic variables } \\
\hline Age & 0.14 & 0.11 & -0.00 & -0.04 \\
\hline Years of experience & -0.24 & -0.24 & -0.09 & -0.03 \\
\hline$R^{2}$ first model & 0.02 & & & \\
\hline \multicolumn{5}{|l|}{ Personal resources } \\
\hline Resilience & & -0.03 & -0.00 & -0.07 \\
\hline Self-efficacy & & 0.13 & 0.12 & 0.04 \\
\hline Optimism & & 0.28 & 0.18 & 0.11 \\
\hline$\Delta \mathrm{R}^{2}$ second model & & 0.12 & & \\
\hline \multicolumn{5}{|l|}{ Job demands } \\
\hline Quantitative demands & & & -0.17 & -0.12 \\
\hline Physical demands & & & -0.18 & -0.19 \\
\hline Emotional demands & & & 0.08 & 0.03 \\
\hline Demands for hiding emotions & & & -0.25 & -0.09 \\
\hline$\Delta \mathrm{R}^{2}$ third model & & & 0.15 & \\
\hline \multicolumn{5}{|l|}{ Job resources } \\
\hline Possibilities for development & & & & 0.07 \\
\hline Degree of freedom at work & & & & -0.03 \\
\hline Influence at work & & & & 0.10 \\
\hline Meaning of work & & & & 0.09 \\
\hline Sense of community & & & & 0.28 \\
\hline Social support & & & & 0.07 \\
\hline Quality of leadership & & & & 0.23 \\
\hline$\Delta R^{2}$ final model & & & & 0.28 \\
\hline $\mathrm{R}^{2}$ final model & & & & 0.57 \\
\hline
\end{tabular}

Bold values represent significance at $\leq 0.05$

leave $(44,45)$ a hierarchical regression analysis was conducted to investigate determinants of child care teachers' job satisfaction.

\section{Job Satisfaction and Centre Type}

The structure of an organization is associated with the nature, quantity, and quality of its out-put. According to Dreeben, schools can be considered as organizations or workplaces which output is a service, in fact, education or teaching (46). This perspective can be extended to day care settings (47). Pedagogical staff experience of their workplace, the way they respond to structural components or psychosocial working conditions has an impact on their job satisfaction.

Regarding the first hypothesis, results revealed differences in day care teachers' job satisfaction with respect to the type of centre. Working for parents' initiatives was associated with greater job satisfaction on average.

This finding is consistent with previous research showing that educators' job satisfaction can differ depending on day care centres ownership $(30,48)$. By contrast, Mullis et al. reported no significant differences between childcare centre directors in their perceptions of job satisfaction (31). This may be due to the fact that the status difference between teachers and directors may moderate their perceptions of school culture (30).

Day care teachers' job satisfaction generally seems to be more interpersonal involving quality of leadership, social support and sense of community. These three features showed the strongest relationship with job satisfaction. In addition to the fact that work stress of employees can be reduced by a supervisor's social support (49), a flattened organizational structure - as it can be found in parents' initiatives - also fosters teachers' involvement and job satisfaction (50).

\section{Determinants of Day Care Teachers' Job Satisfaction}

Day care teachers' job satisfaction was regressed onto various job demands, job resources and personal resources derived from the JD-R model. The results of the analysis indicate that each of these aspects is a vital component of job satisfaction.

The personal resources self-efficacy and optimism in block 2 were significantly associated with job satisfaction and this was 
still true for optimism in the final regression model. This is in line with the previous research, were employees' optimism was related to their job satisfaction (51). Employees who are able to respond to adverse situations with optimism have greater persistence; a requirement for successful adaptation (52).

In the third model quantitative demands, physical demands, and demands for hiding emotions were significantly related to job satisfaction and this was also the case in the final model. The pressure of quantitative demands and time pressure (53), demanding physical working conditions (1), and the emotionally challenging work $(54,55)$ can reduce satisfaction significantly.

The most important factors contributing to job satisfaction in the final model were sense of community and quality of leadership. Relationships with the supervisor are a common source of both satisfaction $(56,57)$ and dissatisfaction $(58,59)$. The supervisor sets the tone of the centre and has an impact on the work environment for the teachers (31). Regardless of the type of centre, an attractive working environment and supportive working conditions contribute enormously to teachers' job satisfaction (48). Therefore, job satisfaction might increase if day care centres possess a favourable school culture in terms of collaboration and mutual support among teachers and supervisor.

The final regression model shows a good fit with $57 \%$ of the observed variance in job satisfaction explained. Most variance was explained by job resources accounting for $28 \%$ unique variance in job satisfaction. This is in line with previous research applying the JD-R model to clarify well-being (10-12). The availability of positive working conditions is prerequisite for well-being factors such as job satisfaction. Inclusion of job resources into the model seems to decrease adverse effects of job demands such as quantitative demands and demands for hiding emotions as proposed by the JD-R model (10).

\section{Limitations}

As with all empirical research the current study is subject to certain methodological limitations. First, it is based on self-report. Early childhood educators may have felt obliged to give socially acceptable rather than honest responses to questions. Moreover, common method variance might have elevated the reported relationships among the variables. For that reason observational measure in the future research would be useful.

Second, the design of the study was cross-sectional and this form of research inhibits causal inferences of the investigated relationships. To fully examine day care teachers' job satisfaction other research designs such as qualitative, mixed method designs or longitudinal studies are needed.

\section{CONCLUSION}

In summary the results of the present study indicate that the type of the centre is a potential factor explaining variations in educators' job satisfaction. The relevance of the interaction between socio-demographic characteristics, psychosocial working conditions, and job satisfaction could be shown.

For occupational health professionals it is important to know what contributes most to day care teachers' job satisfaction and in which work characteristics the most gain is to be expected when they are subject to improvement projects. According to the results of the present study, sense of community and quality of leadership are important factors, as both accounted strongly for variance in job satisfaction.

Altogether results of the present study add to a growing base of knowledge on day care teachers' job satisfaction and provide a valuable basis for the development of solution focused approaches to improve pedagogical staff working conditions.

\section{Conflict of interests}

None declared

\section{Acknowledgements}

This study was supported by the Institution for Statutory Accident Insurance in the Health and Welfare Services.

\section{REFERENCES}

1. Jorde-Bloom P. Teacher job satisfaction: a framework for analysis. Early Child Res Q. 1986;1(2):167-83.

2. Mein G, Martikainen P, Stansfeld SA, Brunner EJ, Fuhrer R, Marmot MG. Predictors of early retirement in British civil servants. Age Ageing. 2000 Nov;29(6):529-36.

3. van den Berg TI, Elders LA, Burdorf A. Influence of health and work on early retirement. J Occup Environ Med. 2010 Jun;52(6):576-83.

4. Whitebook M, Bellm D. Taking on turnover: an action guide for child care center teachers and directors. Washington, DC: Center for the Child Care Workforce; 1999.

5. Sumsion J. Sustaining the employment of early childhood teachers in long day care: a case for robust hope, critical imagination and critical action. Asia Pac J Teach. 2007;35(3):311-27.

6. Howes $\mathrm{C}$, Hamilton $\mathrm{C}$. The changing experience of child care: changes in teachers and in teacher-child relationships and children's social competence with peers. Early Child Res Q. 1993;8(1):15-32.

7. Howes C, Phillips DA, Whitebook M. Thresholds of quality: implications for the social development of children in center-based child care. Child Dev. 1992;63(2):449-60.

8. Phillips D, Mekos D, Scarr S, McCartney K, Abbott-Shin M. Within and beyond the classroom door: assessing quality in child care centers. Early Child Res Q. 2000;15(4):475-96.

9. Kusma B, Nienhaus A, Spallek M, Quarcoo D, Groneberg DA, Mache S. Bidirectional Assessment of Stress, job satisfaction and work ability of Educators in day care centres: a real-time observation study - the study protocol (BASE). J Occup Med Toxicol. 2010 Jun 29;5(1):16.

10. Demerouti E, Bakker AB, Nachreiner F, Schaufeli WB. The job demandsresources model of burnout. J Appl Psychol. 2001 Jun;86(3):499-512.

11. Bos JT, Donders NC, Bouwman-Brouwer KM, Van der Gulden JW. Work characteristics and determinants of job satisfaction in four age groups: university employees' point of view. Int Arch Occup Environ Health. 2009 Nov;82(10):1249-59.

12. Mache S, Vitzthum K, Nienhaus A, Klapp BF, Groneberg DA. Physicians' working conditions and job satisfaction: does hospital ownership in Germany make a difference? BMC Health Serv Res. 2009 Aug 13;9:148.

13. Van Ruysseveldt J. Mental exhaustion and job satisfaction in Flemish workers. Tijdschrift voor Arbeidsvraagstukken. 2006;22(4):328-43. (In Dutch.)

14. Llorens S, Bakker A, Schaufeli W, Salanova M. Testing the robustness of the job demands-resources model. Int J Stress Manag. 2006;13(3):378-91.

15. Xanthopoulou D, Bakker AB, Demerouti E, Schaufeli WB. The Role of personal resources in the job demands-resources model. Int J Stress Manag. 2007;14(2):121-41.

16. Bakker AB, Hakanen JJ, Demerouti E, Xanthopoulou D. Job resources boost work engagement, particularly when job demands are high. J Educ Psychol. 2007;99(2):274-84.

17. Meijman TF, Mulder G. Psychological aspects of workload. In: Drenth PJD, Thierry H, editors. Handbook of work and organizational psychology: personnel psychology. Hove, UK: Psychology Press; 1998. p. 5-33. 
18. Rudow B. Working conditions for day care teachers. High psychological stress. Bildung und Wissenschaft. 2004(6):6-13. (In German.)

19. Dippelhofer-Stiem B, Kahle I. Empirical analysis of educational work in kindergartens. Zeitschrift für Frauenforschung. 1994;12:111-22. (In German.)

20. Rudow B. Day care teachers' strain, health and safety at work. Mannheim \& Mühlhausen / Thür.: Institut für Gesundheit und Organisation (IGO); 2004. (In German.)

21. Gewerkschaft Erziehung und Wissenschaft. How is the job? Frankfurt am Main: Gewerkschaft Erziehung und Wissenschaft - Hauptvorstand; 2007. (In German.)

22. Fuchs T, Trischler F. Quality of work from the perspective of day care teachers. Results from the survey DGB-Index good work. Stadtbergen: Internationales Institut für Empirische Sozialforschung; 2008. (In German.)

23. Schad M. Education is not childs' play: hazards and stress of pedagogical staff in day care. Frankfurt am Main: Unfallkasse Hessen; 2002. (In German.)

24. Bakker AB, Demerouti E. The Job demands-resources model: state of the art. J Manage Psychol. 2007;22(3):309-28.

25. Simbula S. Daily fluctuations in teachers' well-being: a diary study using the job demands-resources model. Anxiety Stress Coping. 2010 Oct;23(5):563-84.

26. Rice RW, Gentile DA, McFarlin DB. Facet importance and job satisfaction. J Appl Psychol. 1991;76(1):31-9.

27. Horton S. High aspirations: differences in employee satisfaction between university faculty and staff. Appl Res Qual Life. 2006;1(3-4):315-22.

28. Oshagbemi T. Personal correlates of job satisfaction: empirical evidence from UK universities. Int J Soc Econ. 2003;30(12):1210-32.

29. Lu H, While AE, Barriball KL. Job satisfaction among nurses: a literature review. Int J Nurs Stud. 2005 Feb;42(2):211-27.

30. Wong YHP. Kindergarten teachers' perceived school culture and wellbeing: a comparison of non-profit-making and profit-making kindergartens. Early Child Dev Care. 2010;180(3):271-8.

31. Mullis AK, Cornille TA, Mullis RL, Taliano K. Childcare center directors' perceptions of their work environments: a comparison of for-profit and non-profit programs. Early Child Dev Care. 2003;173(5):545-56.

32. De Lange AH, Taris TW, Kompier MAJ, Houtman ILD, Bongers PM. The relationships between work characteristics and mental health: examining normal, reversed and reciprocal relationships in a 4-wave study. Work Stress. 2004;18(2):149-66.

33. Wong CS, Hui C, Law KS. A longitudinal study of the job perception-job satisfaction relationship: a test of the three alternative specifications. J Occup Organ Psychol. 1998;71(2):127-46.

34. Hobfoll SE, Johnson RJ, Ennis N, Jackson AP. Resource loss, resource gain, and emotional outcomes among inner city women. J Pers Soc Psychol. 2003 Mar; 84(3):632-43.

35. Chang YH, Li HH, Wu CM, Wang PC. The influence of personality traits on nurses' job satisfaction in Taiwan. Int Nurs Rev. 2010 Dec;57(4):47884.

36. Youssef CM, Luthans F. Positive organizational behavior in the workplace: the impact of hope, optimism, and resilience. J Manage. 2007;33(5):774-800.

37. Nübling M, Stößel U, Hasselhorn HM, Michaelis M, Hofmann F. Measuring psychological stress and strain at work - Evaluation of the COPSOQ Questionnaire in Germany. Psychosoc Med. 2006 Oct 18;3:Doc05.

38. Kristensen TS, Hannerz H, Høgh A, Borg V. The Copenhagen Psychosocial Questionnaire - a tool for the assessment and improvement of the psychosocial work environment. Scand J Work Environ Health. 2005 Dec;31(6):438-49.
39. Wagnild GM, Young HM. Development and psychometric evaluation of the Resilience Scale. J Nurs Meas. 1993 Winter;1(2):165-78.

40. Sinclair VG, Wallston KA. The development and psychometric evaluation of the Brief Resilient Coping Scale. Assessment. 2004 Mar;11(1):94-101.

41. Scholler G, Fliege H, Klapp BF. Questionnaire of self-efficacy, optimism and pessimism: reconstruction, selection of items and validation of an instrument by means of examinations of clinical samples. Psychother Psychosom Med Psychol. 1999 Aug;49(8):275-83. (In German.)

42. Jerusalem M, Schwarzer R. Self-efficacy. In: Schwarzer R, editor. Scales for mental state and personality. Freie Universität Berlin: Institut für Psychologie; 1986. p. 15-28. (In German.)

43. Scheier MF, Carver CS. Optimism, coping, and health: assessment and implications of generalized outcome expectancies. Health Psychol. $1985 ; 4(3): 219-47$

44. Coomber B, Barriball KL. Impact of job satisfaction components on intent to leave and turnover for hospital-based nurses: a review of the research literature. Int J Nurs Stud. 2007 Feb;44(2):297-314

45. Larrabee JH, Janney MA, Ostrow CL, Withrow ML, Hobbs GR Jr, Burant $\mathrm{C}$, et al. Predicting registered nurse job satisfaction and intent to leave. J Nurs Adm. 2003 May;33(5):271-83.

46. Dreeben R. The school as a workplace. In: Travers RM, editor. Second handbook on research on teaching. Chicago: Rand McNally; 1973. p. 450-73.

47. Kontos S, Stremmel AJ. Caregivers' perceptions of working conditions in a child care environment. Early Child Res Q. 1988;3(1):77-90.

48. Papanastasiou EC, Zembylas M. Job satisfaction variance among public and private kindergarten school teachers in Cyprus. Int J Educ Res. 2005;43(3):147-67.

49. Luszczynska A, Cieslak R. Protective, promotive, and buffering effects of perceived social support in managerial stress: the moderating role of personality. Anxiety Stress Coping. 2005;18(3):227-44.

50. Miskel C, Fevurly R, Steward J. Organizational structures and processes, perceived school effectiveness, loyalty, and job satisfaction. Educ Adm Q. 1979;15(3):97-118.

51. Luthans F, Avolio BJ, Avey JB, Norman SM. Positive psychological capital: measurement and relationship with performance and satisfaction. Pers Psychol. 2007;60(3):541-72.

52. Seligman MEP. Learned optimism. New York: A. A. Knopf; 1991.

53. Nübling M, Stößel U, Hasselhorn HM, Michaelis M, Hofmann F. Methods for the assessment of mental work load - testing of a measuring procedure (COPSOQ). Bremerhaven: Wirtschaftsverlag NW; 2005. (In German.)

54. Pugliesi K. The consequences of emotional labor: effects on work stress, job satisfaction, and well-being. Motiv Emot. 1999;23(2):125-54.

55. Bulan HF, Erickson RJ, Wharton AS. Doing for others on the job: the affective requirements of service work, gender, and emotional well-being. Soc Probl. 1997;44(2):235-56.

56. Robinson BE. A two-year followup study of male and female caregivers. Child Care Q. 1979;8(4):279-94.

57. Fleischer B. Identification of strategies to reduce turnover among child care workers. Child Care Q. 1985;14(2):130-9.

58. Jorde-Bloom P. Factors influencing overall job satisfaction and organizational commitment in early childhood work environments. J Res Child Educ Education. 1988;3(2):107-22.

59. Ross AL. A study of child care staff turnover. Child Care Q. 1984;13(3):209-24.

Received June 22, 2011 Accepted in revised form June 14, 2012 